\title{
Role of the preferred habitat availability for small shark (Mustelus schmitti) on the interannual variation of abundance in a large Southwest Atlantic Coastal System (EI Rincón, $39^{\circ}-41^{\circ} \mathrm{S}$ )
}

\author{
A.J. JAUREGUIZAR ${ }^{1,2, a}$, R. WIFF $^{3}$ and M. LUZ CLARA ${ }^{2,4}$ \\ ${ }^{1}$ Comisión de Investigaciones Científicas de la Provincia de Buenos Aires (CIC), Calle 526 e/ 10- 11, CP 1900, La Plata, República Argentina \\ 2 Instituto Nacional de Investigación y Desarrollo Pesquero (INIDEP), Paseo Victoria Ocampo No. 1, CP 7600, Mar del Plata, \\ República Argentina \\ ${ }^{3}$ Center of Applied Ecology and Sustainability (CAPES), Pontificia Universidad Católica de Chile, Av. Libertador Bernardo O’Higgins 340, \\ Santiago, Chile \\ ${ }^{4}$ Consejo Nacional de Investigaciones Científicas y Técnicas (CONICET), Moreno 3527, CP 7600, Mar del Plata, República Argentina
}

Received 20 October 2015; Accepted 19 October 2016

\begin{abstract}
Description of habitat preferences in marine fishes is important in order to understand their spatial distribution and ecology, and are one of the first steps towards conservation. In this paper, we evaluate the influence of environmental conditions (temperature, salinity), location (latitude-longitude, depth), time (year) and availability of preferred habitat on the relative biomass of the narrownose smooth-hound shark (Mustelus schmitti) in El Rincón $\left(\sim 38^{\circ}-41^{\circ} \mathrm{S}<50 \mathrm{~m}\right)$, Argentina. We used an extensive database of bottom trawl surveys conducted yearly during southern spring (November-December) between 1994 and 2012, containing 502 sampling stations where relative biomass, environmental variables and location are registered. Relative biomass was modeled using Generalized Additive Models (GAM) in which zeros observations were incorporated using a Tweedie distribution, and model selection was carried out using generalized cross validation values (CGV) and Akaike information criterion (AIC). The best models selected indicate that a combination of location (nearshore areas), depth $(<30 \mathrm{~m})$ and salinity $(\leqslant 33.5)$ was significant in explaining relative biomass across time. In addition, the percentage of preferred habitat by $M$. schmitti, was also a significant predictor for relative biomass and was correlated to the main freshwater discharge previous to the fisheries survey. Discussion focused on understanding the spatial ecology of this species. We highlighted how environmental variables become a key issue to understand biomass indices derived from fishery-independent surveys.
\end{abstract}

Keywords: Habitat preferences / Mustelus schmitti / spatial and temporal distribution / environmental influence / small shark / Southwest Atlantic Coastal System

\section{Introduction}

The narrownose smooth-hound shark (Mustelus schmitti) is the most important elasmobranch species fished in the Southwest Atlantic Coastal System (SWACS) in terms of total catch and economic importance, and is harvested by both, commercial and recreational fisheries (Massa et al. 2004; Oddone et al. 2005). This small shark (maximum total length $=105 \mathrm{~cm}$; Menni 1985) inhabits the Southwest Atlantic, from Río de Janeiro in Brazil $\left(23^{\circ} \mathrm{S}\right.$; Vooren and Klippel 2005) to Puerto Deseado in Argentina $\left(47^{\circ} \mathrm{S}\right.$; Chiaramonte and Petovello 2000) and has been reported in depths up to $200 \mathrm{~m}$ (Menni et al. 2010). High densities have been reported in shallow waters $(<50 \mathrm{~m})$ of SWACS, and also in the coastal estuarine ecosystem of Río de la Plata $\left(34^{\circ}-37^{\circ} \mathrm{S}\right)$ and El Rincón $\left(39^{\circ}-41^{\circ} \mathrm{S}\right)$ (Massa et al. 2004;

a Corresponding author: ajj@inidep.edu.ar
Jaureguizar et al. 2006a; Cortés et al. 2011a). This species inhabits estuarine ecosystems where environmental conditions provide suitable feeding, mating and breeding areas especially during the developmental stages from juvenile to adult (Cousseau 1986; Massa 1998; Cortés et al. 2011a).

Geographic and hydrographic characteristics of estuarine environments greatly determine the ecological functioning of their inhabiting species (Whitfield and Elliott 2002). Estuaries are known to be stressful environments for organisms due to the high degree of variability in their physicochemical characteristics. In particular, most of the environmental variables such as temperature, salinity, dissolved oxygen (DO), turbidity and bed sediment have high variations across time and space (Elliott and Whitfield 2011; Borja et al. 2012). These particular characteristics of estuarine ecosystems determine the spatial distribution at different biological levels of organization within the SWACS, from fish assemblages (Jaureguizar et al. 2003a, 2004, 2006a; Barletta et al. 2010; Garcia et al. 2010) 
and populations (Jaureguizar et al. 2007; Cortés et al. 2011b) to individual life history traits (Jaureguizar et al. 2003b, 2006b, 2008; Cortés et al. 2011a). Changes in the environmental conditions such as freshwater discharge and wind patterns have high influence in shaping the dynamic of the estuarine ecosystems. The intra and inter-annual variations in Río de la Plata freshwater inputs influence the spatial extension of estuarine conditions (along-shore salinity gradient) changing the distribution and abundance of marine and estuarine fish species and their ontogenetic stages (Jaureguizar et al. 2003a, 2006a; Juareguizar and Guerrero 2009). Thus, environmental factors modify the extension of preferred habitats of species such as M. schmitti, across time. Inter-annual variations on the preferred habitats will challenge the way surveys need to be designed in order to produce unbiased and comparable time series of abundance estimates.

M. schmitti inhabits the El Rincón area and shows high seasonal variability of the area-specific density (Massa 1998; Massa et al. 2004; Colautti et al. 2010) which has been associated with reproductive movements to shallower waters, mating and breeding areas, during southern spring (end of November; Cortés et al. 2011a). The largest aggregations of adults associated with the reproductive event are observe at water temperatures above $16.5^{\circ} \mathrm{C}$, occurring mainly at depths shallower than $15 \mathrm{~m}$ (Elisio et al. 2016). Thus, during early developmental stages such neonates and juveniles are usually found in coastal waters whose conditions enable them to increase their individual growth rate (Massa 1998; Colautti et al. 2010; Cortés et al. 2011a). Juveniles remain in shallow waters (0.8$12 \mathrm{~m})$ with relatively low salinities $(<33.5)$ during the first years of life (Cortés et al. 2011a). In addition, adults during non-reproductive season are usually found in deeper waters (50-130 m; Pereyra et al. 2008).

Since 1993, bottom trawl surveys have been conducted in the El Rincón system collecting data to produce estimates of relative biomass using the swept area method for several species, including M. schmitti. Swept area method estimates biomass indices, which are relative to the population biomass. Time series of relative biomass of $M$. schmitti have high variation between years (Cortés 2012). Variations of relative biomass are deemed to be produced by other causes than the survey design, which has relatively maintained operational and sampling locations across years until 2008, after then it was changed to line transect. In addition, life history traits of $M$. schmitti, including slow individual growth rate, late maturity and low fecundity (Cortés 2012) introduce small variations in between-years recruitments, and thus life history traits do not explain the high variation observed in the relative biomass. Therefore, changes in relative biomass need to be studied from a different standpoint. M. schmitti distributions vary in response to environmental conditions (Cortés et al. 2011a; Cortés 2012), hence, estimates of biomass from survey-based estimators whose spatial domain is fixed across time may introduce bias in the stock assessment (Perry and Smith 1994; Shepherd et al. 2002; Stoner 2004), and preclude the interpretation of time series of survey-design densities of fish as an index of biomass. The use of bottom trawl surveys as an index of biomass relies on the assumption that variations in species-specific location density can be explained by true

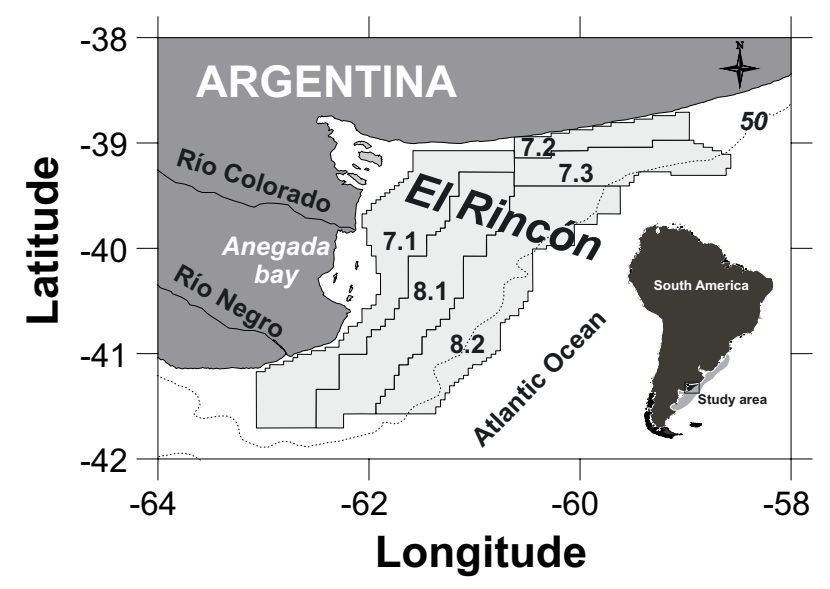

Fig. 1. Map of the study area. Divisions inside the map refer to strata used for abundance estimation. It is indicates the study area (black) and the Mustelus schmitti distribution range (grey, www.fishbase.se).

variation in population biomass. Disentangling the effects of fishing exploitation, availability, variation in recruitment and responses on the distribution to the environment are key issues in understanding survey design density as a relative biomass index. Thus, knowledge about the extent environmental conditions are influencing the density from survey design data in M. schmitti became important when using such data as relative abundance index. Therefore, the main aim of this study is to estimate how the salinity, temperature, depth and freshwater river discharge determine the survey density. To achieve this objective, we use the extensive database available from bottom trawls surveys (swept area method) in the El Rincón system.

\section{Material and methods}

\subsection{Study area}

The coastal area $(<50 \mathrm{~m})$ between $39^{\circ} \mathrm{S}$ and $41^{\circ} \mathrm{S}$ is delimited to the east by low salinity waters of the El Rincón (ER) estuarine system (Fig. 1). The ER estuarine waters $(<30.0$ 33.3) extend from the mouth of the Río Negro to Bahía Blanca at $39^{\circ} \mathrm{S}$, along the Anegada bay. Sea surface temperature displays a pronounced seasonal cycle typical of temperate areas, with a dominant maximum around $18{ }^{\circ} \mathrm{C}$ in the summer and a minimum of $8.2{ }^{\circ} \mathrm{C}$ in the winter (Lucas et al. 2005). The combined discharge of Río Negro (average annual discharge of $945 \mathrm{~m}^{3} \mathrm{~s}^{-1}$ ) and Río Colorado (average annual discharge $99 \mathrm{~m}^{3} \mathrm{~s}^{-1}$ ) form the El Rincón estuarine system (Guerrero and Piola 1997; Guerrero 1998; Lucas et al. 2005). The small vertical gradients in salinity indicated a vertically homogenous or totally mixed estuarine system (Lucas et al. 2005) mainly as result of tidal strength and winds (Acha et al. 2004). Río Negro discharge accounted for almost $90 \%$ of the fresh water input to the El Rincón system, with high inter-annual variations. The southern autumn-winter estuarine signal extended along the coast for around $300 \mathrm{~km}$ between Río Negro and Bahía Blanca, while during springsummer the ER signal extended $400 \mathrm{~km}$ along the coast, first north to Bahía Blanca and then to the east, along the coast 
(Lucas et al. 2005). The El Rincón estuarine regime area varied between $10000 \mathrm{~km}^{2}$ (autumn-winter period) and $15000 \mathrm{~km}^{2}$ (spring-summer period). In the springs of 1996 and 1998 (La Niña years) the estuarine area was reduced to less than $5000 \mathrm{~km}^{2}$ (Lucas et al. 2005).

\subsection{Material and data analysis}

Data regarding fish density and environmental variables (salinity, temperature and depth) were obtained during southern spring (November-December) from bottom trawls surveys conducted by the Instituto Nacional de Investigación y Desarrollo Pesquero (INIDEP). Data corresponded to a total of 502 bottom trawls over the span of eight years (78 in 1994, 47 in 1998, 48 in 1999, 63 in 2003, 78 in 2005, 74 in 2008, 58 in 2011, and 56 in 2012). Operational and sampling characteristics of these trawls were homogeneous during this timeframe. Further operational details of these surveys can be found in Jaureguizar et al. (2006a). In each sampled station, bottom temperature and salinity were measured using a ConductivityTemperature-Depth (CTD) profiler with a sampling rate of two scans per second and operated with a speed of $0.5 \mathrm{~m} \mathrm{~s}^{-1}$, corresponding to a resolution of one vertical meter, with a precision of $\pm 0.03{ }^{\circ} \mathrm{C}$ for temperature and \pm 0.05 for salinity.

Average density in ton per square nautical miles $\left(\mathrm{t} * \mathrm{~nm}^{-2}\right)$ was used as an index of biomass. Estimation of biomass considers a separation of the area into five pre-defined strata (Fig. 1). This density was calculated scaling up the average density over all fishing hauls in each stratum to the total surface area of the stratum. In order to deal with extreme values in density, only the 3 rd quartile (75 percentile) $* 1.5$ interquartile range of the density distribution by survey was used as upper limit of the maximum observed density. Data points falling outside the upper limit wereset to that upper limit for further analysis. In order to improve statistical performance of the density estimator, five strata were considered in the bottom trawl surveys, as suggested by Ruarte (2003).

Differences of temperature and salinity across years were evaluated using one-way analysis of variance (ANOVA) Although some transformations were applied, variance was not homogeneous (Bartlett test) and, thus, a significance level $(\alpha)$ of 0.01 was used in order to control Type I error. When the null hypothesis was rejected in the ANOVA, the Scheffe test was computed to corroborate these results.

The average density was modeled using a Generalized Additive Model (GAM; Hastie and Tibshirani 1990) considering environmental variables (depth, temperature and salinity) and geographic location (latitude and longitude) and suitable habitat as covariates. GAM is a statistical method that enables the user to model non-linear responses to covariates and permits the implementation of several statistical distributions. We defined as "suitable habitat" the percentage of the ER survey area covered with environmental conditions with positive anomalies over the average density. The most important environmental covariate to explain density was interpolated to generate a grid of $\left(0.1^{\circ}\right.$ lat $\times 0.1^{\circ}$ long $)$, and then the percentage of grid with the suitable environmental variable was calculated. Interpolation was only applied to calculate percentage of suitable habitat. Given the nature of the data, which includes a significant amount of zero values, the compound Poisson distribution was used to model the response variable. Compound Poisson belongs to the Tweedie family distribution, which included those models with exponential dispersion where there is a power relationship between the median and the variance (Shono 2008; San Martín et al. 2013). Specific probability distributions belonging to the Tweedie family are conditioned on the particular values that the parameter $p$ can take, e.g. when parameter $p$ takes values of 1,2 or 3 , this corresponds to Poisson, Gamma and inverse Gaussian distributions, respectively. We are interested here in modeling values of $p$ between 1 and 2 which defined a compound Poisson and allow us to model positive and zero observations at once. The $\mathrm{p}$ parameter was previously estimated by maximum likelihood (Shono 2008). The response variable was the average density of $M$. schmitti $\left(\mathrm{t} * \mathrm{~nm}^{-2}\right)$ by sampling station. To avoid collinearity, a correlation matrix of environmental variables was computed and only those not significantly correlated variables were included for further analysis, following Zuur et al. (2010). Predictive variables with variance inflation factors (VIF) greater than 3 were not considered. In addition, when two correlated environmental variables had a correlation greater than 0.7 , only the one that presented better explained variance by itself on modeling density was retained. All statistical analyses were carried out in $\mathrm{R}$ programming language (Ihaka and Gentleman 1996; http://www.r-project.org) using mgcv (Wood 2006), MASS (Venables and Ripley 2002) and Tweedie packages (Dunn 2009). Model selection was conducted using generalized cross validation values (GCV) and Akaike information criterion (AIC; Wood 2006).

In order to generate maps of suitable habitats for $M$. schmitti, we analyzed the environmental variables with the highest explained deviance on the retained models (temperature and salinity), and then we defined the lower and upper bounds for positive influence over the response variable as limits for suitable habitats. Thus defined a sort of "environmental window" where response variable (biomass) is maximum. We then mapped these characteristics of suitable habitats across time by interpolating these limits for environmental variables using a $0.1^{\circ}$ lat $\times 0.1^{\circ}$ long grid using the inverse distance to square.

Pearson correlations between the percentage of the ER survey area covered $(H)$ with environmental conditions with positive influence over the average density of $M$. schmitti (obtained from GAM-tweedie model) and the mean monthly freshwater discharge (Río Negro and Colorado), previous to assessment cruises, were estimated. The values of average monthly flow $\left(\mathrm{m}^{3} \mathrm{~s}^{-1}\right)$ of the Río Colorado (at Pichi Mahuida station: 3849'17.90”S-6458'53.20”W) and Río Negro (at Primera Angostura station $40^{\circ} 27^{\prime} \mathrm{S}-63^{\circ} 47 \mathrm{~W}$ ) were obtained from section de Recursos Hídricos de la Nación (http://www. hidricosargentina.gov.ar/).

\section{Results}

\subsection{Environmental conditions}

Salinity and temperature time series had large inter-annual variations. Salinity fluctuated significantly between most years 

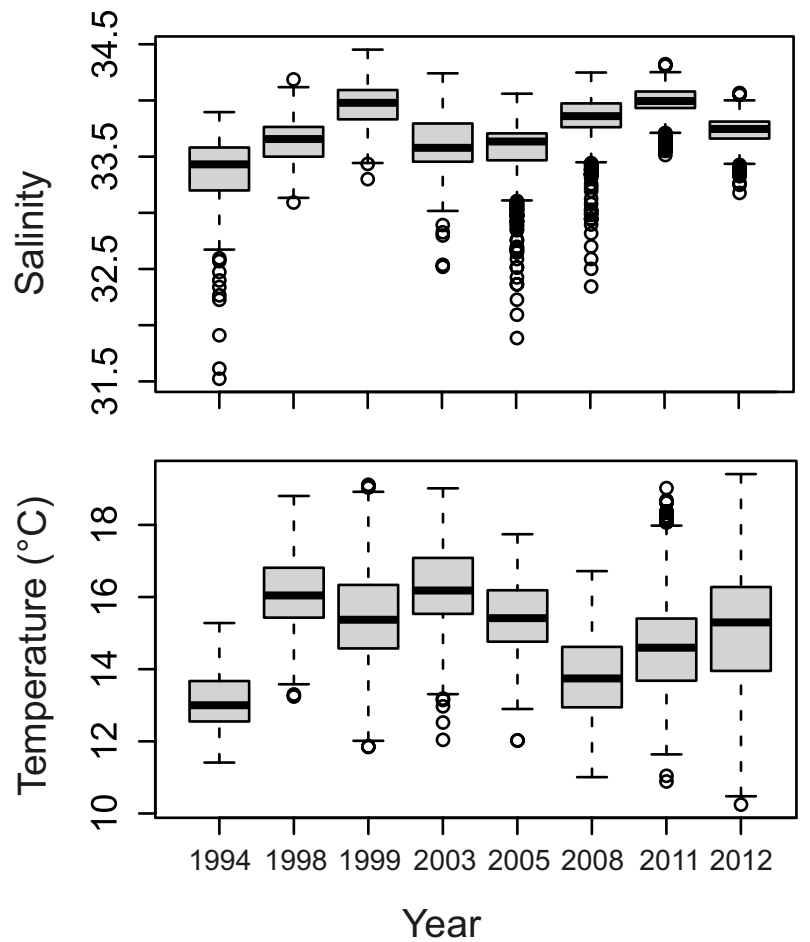

Fig. 2. Boxplot of salinity and temperature from abundance surveys in the El Rincón area during spring.

( $p<0.05$, Tab. 1$)$, and the mean annual salinity ranged from 33.3 (1994) to 34.0 (2011) (Fig. 2). Temperature had stronger inter-annual variability than salinity and differed significantly between most years ( $p<0001$, Tab. 1), as the mean annual value ranged from 13.1 in 1994 to 16.3 recorded in 2003 (Fig. 2).

The average monthly flow of the Río Colorado (mean $\left.109.43 \mathrm{~m}^{3} \mathrm{~s}^{-1}\right)$ represented $\sim 16 \%$ of the flow of the Río Negro (mean $695.47 \mathrm{~m}^{3} \mathrm{~s}^{-1}$ ) (Fig. 3). The discharge pattern had higher intra-annual variation in the Río Negro than the Río Colorado that usually presented a minimum flow between April and July. On the other hand, Río Negro discharge had a different intra-annual pattern with a maximum usually in southern winter between June and September (Fig. 3). In addition, both rivers had important inter-annual variations in the monthly flow, particularly in the months before the survey took place (November-December). 1994 and 2005 flows were higher than average across time, other years had minor flow (1999, 2008, 2011), or exhibited a downward trend toward the end of the year (1998, 2003, 2012) (Fig. 3).

\subsection{Biological conditions}

M. schmitti was on average caught in $29 \%$ of total sampling stations ( $n=502)$, and the proportion of sampled stations with zero catch varied across years, with the lowest value registered during $2012(10.7 \%)$ and the highest during 2008 and 1998 (45.9 and 46.8\% respectively). The relative biomass had a downward trend across years in the total area of ER. Although, a decrease of 76\% was calculated between 1994 
Table 2. Percentage of explained deviance, the generalized 1 cross validation value (GCV) and Akaike's information criterion (AIC) of the main models applied. $f_{0}$ represents the intercept in each model and $f$ is the smoothing based on thin plate regression spline. Explanatory variables are years as factor $(Y)$, latitude and longitude (Lat, Long), temperature $(T)$, salinity $(S)$, depth $(Z)$ and suitable habitat, the percentage of the El Rincón survey area covered with salinity conditions with positive influence over the average density, $(H)$. $E[A]$, is the predicted expected biomass All models considers Tweedie family distribution for modeling error.

\begin{tabular}{ccccc}
\hline & Model & D. explained & GCV & AIC \\
\hline 1 & $E[A]=f_{0}+f(Z)$ & 0.193 & 3.360 & 2409.84 \\
2 & $E[A]=f_{0}+f(S)$ & 0.159 & 3.526 & 2441.82 \\
3 & $E[A]=f_{0}+f(T)$ & 0.046 & 4.045 & 2527.27 \\
4 & $E[A]=f_{0}+f($ Lat, Long) & 0.346 & 2.9216 & 2313.29 \\
5 & $E[A]=f_{0}+Y$ & 0.191 & 3.4452 & 2423.02 \\
6 & $E[A]=f_{0}+H$ & 0.194 & 3.4261 & 2423.02 \\
7 & $E[A]=f_{0}+f(S)+f(Z)+f($ Lat, Long) & 0.409 & 2.6985 & 2267.31 \\
8 & $E[A]=f_{0}+f(S)+f(Z)+f($ Lat, Long $)+H$ & 0.519 & 2.2523 & 2160.93 \\
9 & $E[A]=f_{0}+f(S)+f(Z)+f($ Lat, Long $)+Y$ & 0.519 & 2.2523 & 2160.93 \\
10 & $E[A]=f_{0}+f(S)+f(Z)+f($ Lat, Long $)+Y+H$ & 0.519 & 2.2523 & 2160.93 \\
11 & $E[A]=f_{0}+f(S)+f(T)+f($ Lat, Long $)$ & 0.419 & 2.6606 & 2261.09 \\
12 & $E[A]=f_{0}+f(S)+f(T)+f($ Lat, Long $)+H$ & 0.522 & 2.2537 & 2160.41 \\
13 & $E[A]=f_{0}+f(S)+f(T)+f($ Lat, Long $)+Y$ & 0.522 & 2.2537 & 2160.41 \\
14 & $E[A]=f_{0}+f(S)+f(T)+f($ Lat, Long $)+Y+H$ & 0.522 & 2.2537 & 2160.41 \\
\hline
\end{tabular}

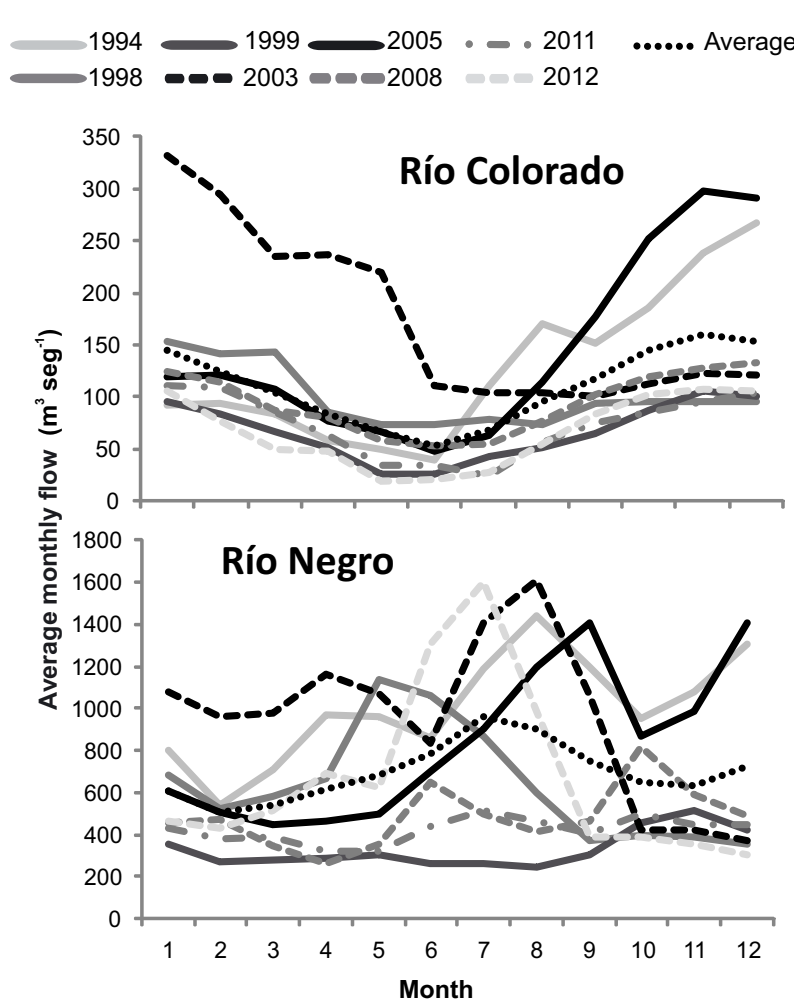

Fig. 3. Average monthly flow $\left(\mathrm{m}^{3} \mathrm{seg}^{-1}\right)$ of Río Colorado and Río Negro in the El Rincón Area

(72 165 t) and 2012 (16674 t), low values appear in 1998 and 2012, with the lowest in 2008 and the highest in 2005 (Fig. 4).

The analysis of variance inflation factors (VIF) of predictive variables had values lower than 3 , and the correlation analysis only presented a high negative correlation between temperature and depth $(-0.7)$. This result indicates a decrease in temperature with depth. To avoid collinearity, this combination of predictors was excluded when modeling the relative biomass.

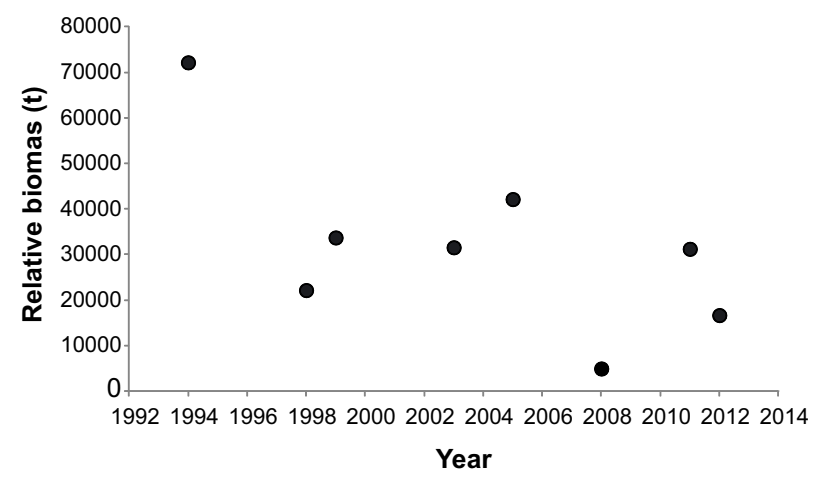

Fig. 4. Relative biomass ( $\mathrm{t}$ ) of Mustelus schmitti in the El Rincón area registered during Southern Spring surveys

Considering different combinations of predictors, a total of 22 models for all years combined were evaluated. For sake of brevity, Table 2 only showed the main models implemented. The smoothness of location (Latitude-Longitude, Model 4), depth (Model 1) and salinity (Model 2) were the most important predictive variables to modeling $M$. schmitti relative biomass (Tab. 2). The models indicated that M. schmitti had higher preference for coastal and shallow waters $(<30 \mathrm{~m})$ with salinity lower than 33.5, while temperature (Model 3) was less important (Fig. 5). Taking into account the high importance of salinity, a model considering the surface of area covered by salinity between 32 and 33.5, suitable habitat (Model 6, Fig. 5), for all years combined was also evaluated and had a higher deviance explained than the model considering time as predictor (Model 5). The models considering depth instead of temperature, exhibited a lower percentage of the total deviance (Tab. 2).

Models 12, 13 and 14 had higher explained deviance, lower GCV and the lowest AIC (Tab. 2, Fig. 6). These models presented a satisfactory goodness-of-fit meaning that the error distribution chosen was adequate to describe the relative biomass in this species. Model 12 considered the combined smoother 

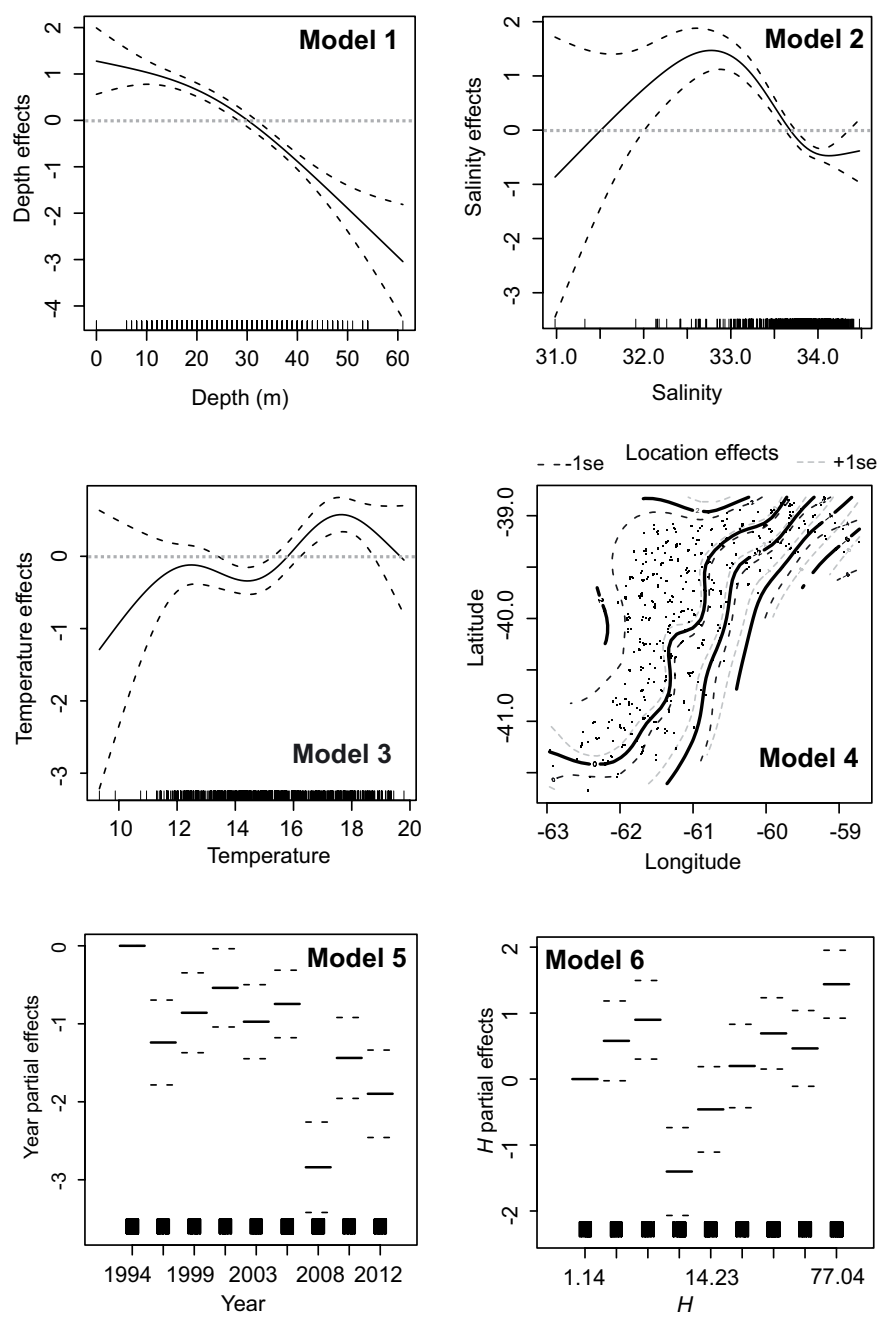

Fig. 5. Response variable (relative biomass) according to the predictive variables used in the univariate models $(1,2,3,4,5,6)$.

for salinity, temperature, location and percentage of ER area covered with preferred salinities $(H)$, while Model 13 considered time (year) instead of coverage of preferred habitat $(H)$, and Model 14 operates with both predictor variables (Tab. 2 ). These three models were satisfactory and presented similar parsimony. Thus, these models were comparable in the statistical performance, thus in order to choose the best model to describe our data we used a biological criterion. First, model 14 had one extra parameter and thus it was discard for further analysis. Thus competing models were 12 and 13, which the only difference is either using habitat preference (model 12), or year (model 13) as factors. We chose model 12 as the best model, because habitat preference is a more meaningful predictor that time alone. Habitat preference implicitly included time because it was constructed on a yearly basis and it also integrated areas with preferred salinities. In addition, model 13 did not have predictive power as each year had its own offset and it cannot be predicted, however, habitat preference in model 12 can be calculated allowing a prediction of its offset.

Bottom salinity had important inter-annual variation in the spatial distribution producing prevalent changes in location and extension of preferred habitat by M. schmitti $(<33.6$,
Table 3. Pearson correlation between the mean monthly flow of Riio Colorado and Negro, with the total flow in the months prior to the survey cruises and the percentage of area covered with salinities lower than 33.6. The $p$ indicates the probability and $r^{2}$ the coefficient of determination.

\begin{tabular}{ccccc}
\hline Month & & Colorado & Negro & Total \\
\hline June & $p$ & 0.2447 & 0.34952 & 0.30417 \\
& $r^{2}$ & 0.2204584 & 0.1487105 & 0.1738056 \\
July & $p$ & 0.052485 & 0.15231 & 0.11282 \\
& $r^{2}$ & 0.4921303 & 0.3092806 & 0.3647798 \\
August & $p$ & 0.0013609 & 0.010967 & 0.0072561 \\
& $r^{2}$ & 0.8401556 & 0.6871084 & 0.7256143 \\
September & $p$ & 0.060377 & 0.024263 & 0.024643 \\
& $r^{2}$ & 0.4704314 & 0.5986891 & 0.5967563 \\
October & $p$ & 0.14657 & 0.27892 & 0.22984 \\
& $r^{2}$ & 0.3165413 & 0.191004 & 0.2294027 \\
November & $p$ & 0.12754 & 0.11781 & 0.11429 \\
& $r^{2}$ & 0.3430093 & 0.3569824 & 0.3624401 \\
\hline
\end{tabular}

Fig. 7). In some years, the preferred habitat covered more than $65 \%$ of the total area of ER (1994), in others $~ 30 \%$ (1998, 2003, 2005), 15-10\% $(2012,2008)$ or as little as 5\% (1999, 2011).

The area covered with salinities preferred by $M$. schmitti $(<33.6)$ presented a positive correlation with freshwater discharge during previous months of the survey. A significant correlation between salinity and average freshwater discharge was found during August and September (Tab. 3). In addition, relative biomass had a weaker but positive and significant correlation ( $p=0.05, r^{2}=0.49$ ) with the proportion of ER covered with salinities preferred by M. schmitti (<33.6) (Fig. 8).

\section{Discussion}

M. schmitti distribution was highly related to coastal environmental conditions in the El Rincón (ER) area, and best combined model (\# 12) indicated that the inter-annual variations on its relative biomass were influenced by changes in the availability of preferred environmental conditions. Geographic location (latitude-longitude used as measure of spatial location), depth and salinity had significant effects on the biomass distribution of $M$. schmitti, with preference for shallow waters $(<30 \mathrm{~m})$ and salinities lower than 33.5. These results agreed with those reported in Cortés (2012), in which abundance of this species in ER increased with temperatures higher than 18 ${ }^{\circ} \mathrm{C}$ and lower salinities $(\leqslant 33.5)$. In addition, we proposed that the percentage of ER covered with salinities $\leqslant 33.5$ (availability of preferred habitat) was highly relevant in explaining the inter-annual changes in the relative biomass of M. schmitti. Expansion and contraction of preferred habitat for this species was highly correlated with the rivers' discharge in months before the survey took place (end of November).

Habitat selection by shark in coastal environments is relates with abiotic factors such as temperature and salinity, as well as ecological factors such as prey availability, predation risk, and competition (Sims 2003; Simpfendorfer and Heupel 2004; Speed et al. 2010; Simpfendorfer et al. 2011). The size class spatial-seasonal distribution pattern of M. schmitti, 

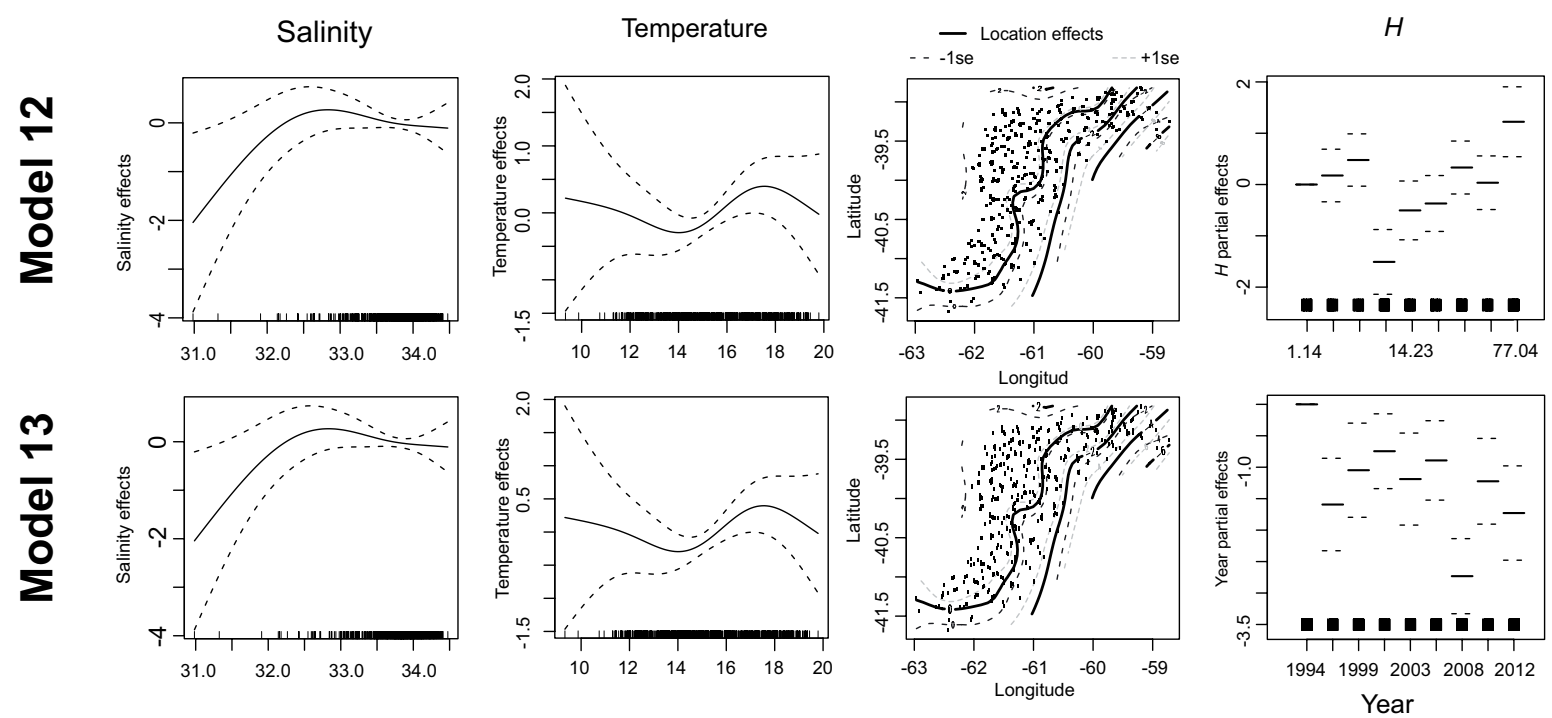

Fig. 6. Response variable (relative biomass) according to the predictive variables used in the combined models (see Tab. 2 for models description). $H$ percentage of the El Rincón survey area covered with salinity conditions with positive influence over the average density.
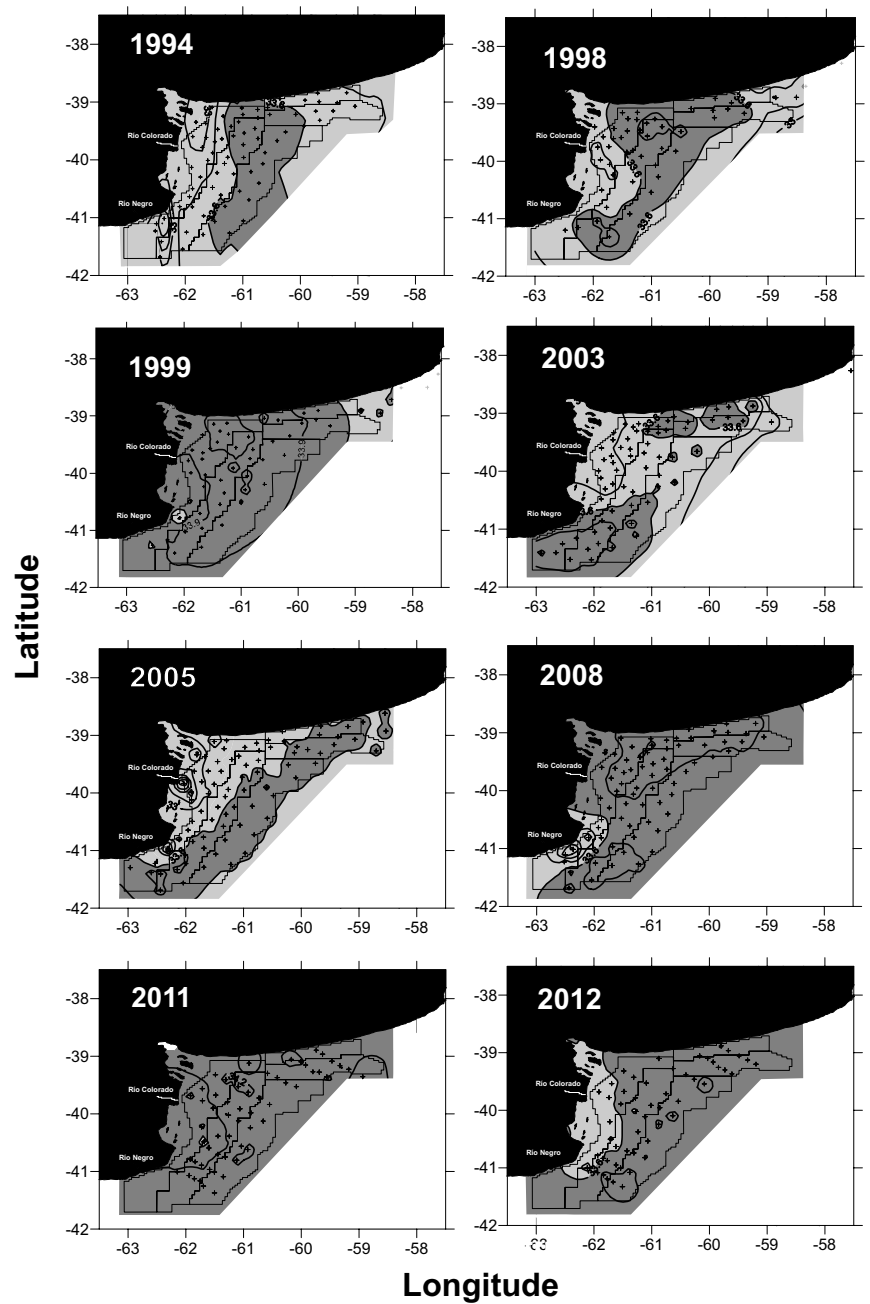

Fig. 7. Spatial distribution of bottom salinity, and the area covered with salinities that have higher (light gray) or lower (dark gray) preferences for Mustelus schmitti. The crosses (+) represent the station sampled each year.

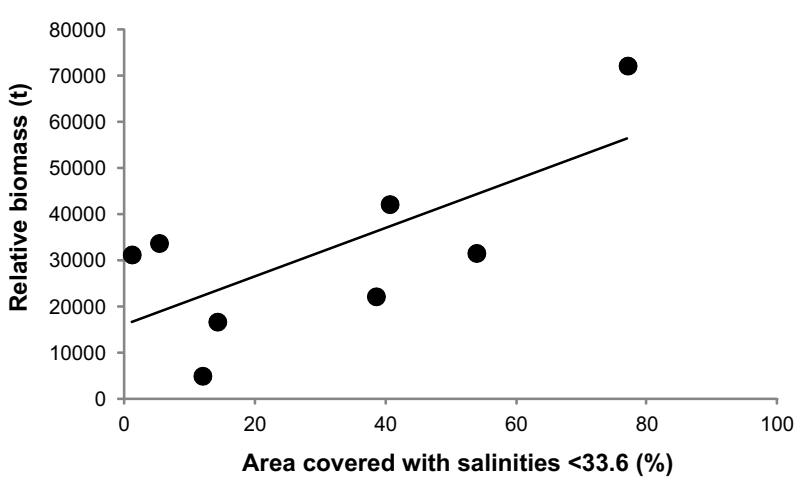

Fig. 8. Relationship between relative biomass ( $\mathrm{t}$ ) of Mustelus schmitti and the area covered with its preferred salinities $(<33.6)$ in the El Rincón area during Southern Spring surveys.

is associated with ontogenetic movements from the nursery areas to deeper waters through development (Cortés et al. 2011a). Neonates and juveniles are predominant in warm and brackish coastal waters, and larger individuals are associated with deeper salty coastal waters (during the non-reproductive season) or nearshore brackish water (during reproductive season, Cortés et al. 2011a). The preference for shallower and warmer waters with high food availability for neonates and juveniles during the reproductive season might be related with maximizing growth rates, rather than predator avoidance. The ER coastal environment offers little refuges, therefore the predator avoiding strategy is less probable and the habitat selection driver appear to be related with the food availability and environmental condition that allow a faster growth (see Cortés et al. 2011a). In the other hand, adults $M$. schmitti are mainly associated with depth and temperature environments and during the reproductive season, they segregate into pre- or post-mating stages (Cortés et al. 2011a). Selection for a preferred salinity range may also minimize energetic costs associated with osmoregulation (Heupel and Simpfendorfer 2008) 
or serve as predator avoidance (Simpfendorfer et al. 2011). However, no work has been done yet to explore these topics on $M$. schmitti behavior.

The high influence that the extension of area covered with low salinities had on the explanation of relative biomass of M. schmitti allows to hypothesize that inter-annual variation of relative biomass was highly determined by movement of those individuals that initially inhabit nearshore areas toward those where the survey sampling is conducted. Therefore, interannual changes in the relative biomass were highly reliant to the availability of fishes in the survey area because of changes in the areas covered with low salinity. Anegada Bay (a shallow area located in the southwest of ER, Fig. 1) is the main nursery and mating area of $M$. schmitti in which the reproductive season takes place in southern spring (Colautti et al. 2010). During this season, high freshwater discharges produce changes in the nearshore oceanographic conditions providing less favorable conditions for mating and breeding (Cortés 2012). This produces a movement of individuals toward neighboring deeper areas, increasing also the chances of being available for or detected by the survey. Considering the size class spatial distribution patterns of M. schmitti (Cortés et al. 2011a; Cortés 2012), movement of individuals suggested in this study will affect the population structure in the nearshore area as too in the fishery survey area. Further studies are required to understand how the environment changes would affect the population structure available in both area and its ecological determinants.

Changes in relative biomass of $M$. schmitti in the El Rincón area had smooth variations across time with the habitat availability. However, there was a high inter-annual variation in the relative biomass which can be related to between-year variability in the suitable habitat sampled. Relative biomass index of M. schmitti had high inter-annual variations. It is unlikely that this high variation of the biomass index between years was due to variations of the real population biomass. In harvested populations, changes in abundance mainly obey to changes in the age-specific total mortality and recruitment among years. Elasmobranch species, such as $M$. schmitti, are being characterized as long-lived, late maturing and low-resilience species whose populations conformed to several age classes. These life history traits also entail a low variability of recruitment of available ages (Cortés 2012). In addition, fishing mortality has been relatively stable in this fishery. The landings and catch rate of M. schmitti in the Argentine-Uruguayan Common Fishing Zone, northern coastal area of ER, are stable since 1992 (Hozbor et al. 2014). Thus, we interpreted these inter-annual changes in the relative biomass as an artifact of the sampling survey because of the re-arrangement of the spatial biomass of M. schmitti with the environmental variables as shown in our results.

The complex life history, seasonal movements, and a population of $M$. schmitti dispersed over a relatively large area challenges the understanding and the potential use of the data derived from surveys. This is highly relevant when modeling population biomass of this species, because fisheryindependent relative biomass indices are usually the most important information in stock assessment. Unfavorable environmental conditions (e.g., high freshwater discharge) may reduce the availability of a species to the survey and, thus, create bias in the biomass estimates (Smith and Page 1996; Shepherd et al. 2002). It is commonly assumed that catchability and its subcomponents, availability and efficiency, are time-invariant (Walters and Martell 2004). However, for a species like $M$. schmitti whose range shifts seasonally, timing of sampling and inter-annual variation in environmental drivers may bias results as presented here. Our analysis revealed higher biomass at salinities lower than 33.5, with interannual variations driven by changes in river discharge that determined salinity and thus the availability of preferred habitat. The Negro river discharge accounted for almost $90 \%$ of the freshwater inputs to the ER system and it had both seasonal and inter-annual variations (Pasquini and Depetris 2007). All major Patagonian rivers (e.g. Negro and Colorado rivers) had an inter-annual frequency in the range of $\sim 2$ to $\sim 7$-year corresponding with the Southern Oscillation Index (SOI) (Pasquini and Depetris 2007). This indicated that the occurrence of events such as the ENSO are clearly discernible in the ER system, and they will have profound effect on salinity and spatial coverage of preferred habitat, and thus the manner we interpret changes in relative biomass of $M$. schmitti.

Main results shown in this study confirmed that the $M$. schmitti distribution was highly related to coastal environmental conditions in the ER area, and the inter-annual variations on its relative biomass were highly influenced by variations in the availability of preferred environmental conditions throughout the years. This result is particularly important to understand biomass indices derived from fishery-independent surveys as an unbiased biomass index. In the case of $M$. schmitti in El Rincón, survey-based biomass index is biased because it does not incorporate environmental variability to standardize or correct such indices on an integrated stock assessment model. High inter-annual variability of the biomass index will produce high variability on the population biomass estimated by stock assessment and, thus, results are biased and misleading, unusable to achieve sustainable exploitation. Following Wilberg et al. (2010), there are two ways to deal with such bias in the biomass index when estimating population biomass. First, carrying out a standardization of the biomass index to incorporate environmental variable and, thus, filter out the year effect, which is usually used as an index of biomass. Second, modeling catchability to allow inter-annual variations being a function of environmental variables (Fox 1974; Fréon 1988; Chen et al. 2008). In this work, we contributed to identify the main environmental variables that affect the change in the relative biomass of $M$. schmitti in El Rincón. These results contributed to understand the spatial ecology and demography of this species, but they also can be used as base analysis to produce unbiased biomass estimates by both, standardizing this survey biomass index, or modeling time-variant and environmental-dependent catchability.

Acknowledgements. We are grateful to three anonymous reviewers for their valuable comments and suggestions that greatly improved an early version of this manuscript. The authors are grateful to Natalia Hozbor for providing the INIDEP database. Rodrigo Wiff was funded by Conicyt-Fondecyt post doctoral project No. 3130425 
and by CAPES project Conicyt FB 0002 (2014). INIDEP contribution No. 2024.

\section{References}

Acha M.E., Mianzan H.M., Guerrero R.A., Favero M., Bava J., 2004, Marine fronts at the continental shelves of austral South America: physical and ecological processes. J. Marine Syst. 44, 83-105.

Barletta M., Jaureguizar A.J., Baigun C., Fontoura N.F., Agostinho A.A., Almeida-Val V.M.F., Val A.L., Torres R.A., JimenesSegura L.F., Giarrizzo T., Fabre N.N., Batista V.S., Lasso C., Taphorn D.C., Costa M.F., Chaves P.T., Vieira J.P., Correa M.F.M., 2010, Fish and aquatic habitat conservation in South America: a continental overview with emphasis on neotropical systems. J. Fish Biol. 76, 2118-2176.

Borja A., Basset A., Bricker S., Dauvin J., Elliot M., Harrison T., Marques J., Weisberg S., West R., 2012, Classifying ecological quality and integrity of estuaries. In: Wolanski E., McLusky D. (Eds.), Treatise on Estuarine and Coastal Science Waltham, Academic Press, pp. 125-162.

Chen Y., Jiao Y., Sun C., Chen X., 2008, Calibrating virtual population analysis for fisheries stock assessment. Aquat. Living Resour. 21, 89-97.

Chiaramonte G.E., Pettovello A.D., 2000, The biology of Mustelus schmitti in southern Patagonia, Argentina. J. Fish Biol. 57, 930 942.

Colautti D., Baigun C., Lopez Cazorla A., Llompart F., Molina J.M., Suquele P., Calvo S., 2010, Population biology and fishery characteristics of the smooth-hound Mustelus schmitti in Anegada Bay, Argentina. Fish. Res. 106, 351-357.

Cortés F., 2012, Hábitats esenciales de condrictios (Chondrichthyes) costeros, y su relación con los procesos oceanográficos Tesis Doctoral Universidad Nacional de Mar del Plata, 220 p, http:// www.oceandocs.org/handle/1834/4524. Accessed 06 August 2015.

Cortés F., Jaureguizar A.J., Menni R.C., Guerrero R.A., 2011a, Ontogenetic habitat preferences of the narrownose smooth-hound shark, Mustelus schmitti, in two Southwestern Atlantic coastal areas. Hydrobiologia 661, 445-456.

Cortés F., Jaureguizar A.J., Guerrero R.A., Dogliotti A., 2011b, Influence of estuarine and continental shelf water advection on the coastal movements of apron ray, Discopyge tschudii, in the Southwestern Atlantic. J. Appl. Ichthyol. 27, 1278-1285.

Cousseau M.B., 1986, Estudios biológicos sobre peces costeros con datos de dos campañas de investigación realizadas en 1981 VI El gatuzo (Mustelus schmitti). Publ. Com. Tec. Mix. Fr. Mar. 1, 60-65.

Dunn P.K., 2009, Tweedie: Tweedie exponential family models R package version 2.0.0.

Elisio M., Colonello J.H., Cortés F., Jaureguizar A.J., Somoza G.M., Macchi G.J., 2016. Aggregations and reproductive events of the narrownose smooth-hound shark, Mustelus schmitti, in relation to temperature and depth in coastal waters of the southwestern Atlantic Ocean $\left(38-42^{\circ} \mathrm{S}\right)$. Mar. Freshwater Res.

Elliott M., Whitfield A.K., 2011, Challenging paradigms in estuarine ecology and management. Estuar. Coast. Shelf S. 94, 306-314.

Fox W.W. Jr, 1974, An overview of production modeling, Col. Vol. Sci. Pap. ICCAT 3, 142-156.

Fréon P., 1988, Introduction of environmental variables into global production models. In: Wyatt T., Larraeneta M.G. (Eds.), International symposium on long-term changes in marine fish populations, Vigo, Spain: Consejo Superior de Investigaciones Científicas, pp. 481-528.
García M., Jaureguizar A.J., Protogino L., 2010, Fish assemblages across the marine to low salinity transition zone of Rio de la Plata estuary, South America. L.A.J.A.R. 38, 81-96.

Guerrero R.A., 1998, Oceanografía física del estuario del Río de la Plata y el sistema costero de El Rincón. In: Lasta C. (Ed.), Resultados de una campaña de evaluación de recursos demersales costeros de la Provincia de Buenos Aires y del litoral uruguayo Noviembre 1994. INIDEP Informe Técnico 21, 29-54.

Guerrero R.A., Piola A.R., 1997, Masas de agua en la plataforma continental. In: Boschi E., (Ed.), El Mar Argentino y sus Recursos Pesquero, Tomo I: Antecedentes históricos de las exploraciones en el mar y las características ambientales Instituto Nacional de Investigación y Desarrollo Pesquero, Mar del Plata, Argentina, pp. 107-119.

Hastie T.J., Tibshirani R.J., 1990, Generalized Additive Models, Chapman and Hall, New York.

Heupel M.R., Simpfendorfer C.A., 2008, Movements and distribution of young bull sharks (Carcharhinus leucas) in a variable estuarine environment. Aquatic Biol. 1, 277-289.

Hozbor N., Cortés F., Pérez M., Massa A., 2014, Índice de abundancia de gatuzo (Mustelus schmitti), pez angel (Squatina guggenheim) y rayas (Rajidae) en el área del tratado del Río de la Plata y su Frente Marítimo. INIDEP Informe de Investigación 64, $20 \mathrm{pp}$, http://www.inidep.edu.ar/publicaciones/catalogo/ informes-de-investigacion-2013-2/. Accessed 06 August 2015.

Ihaka R., Gentleman R., 1996, R: a language for data analysis and graphics J. Comput. Graph. Stat. 5, 299-314

Jaureguizar A., Menni R., Bremec C., Mianzan H., Lasta C., 2003a, Fish assemblage and environmental patterns in the Río de la Plata estuary. Estuar. Coast. Shelf S. 56, 921-933.

Jaureguizar A., Bava J., Carozza C.R., Lasta C., 2003b, Distribution of the whitemouth croaker (Micropogonias furnieri) in relation to environmental factors at the Rio de la Plata estuary, South America. Mar. Ecol. Prog. Ser. 255, 271-282.

Jaureguizar A., Menni R., Guerrero R., Lasta C., 2004, Environmental factors structuring fish communities of the Rio de la Plata estuary. Fish. Res. 66, 195-211.

Jaureguizar A., Menni R., Lasta C., Guerrero R., 2006a, Fish assemblages of the Northern Argentine Coastal System: spatial patterns and their temporal variations. Fish. Oceanogr. 15, 326-344.

Jaureguizar A.J., Guerrero R.A., 2009, Striped weakfish (Cynoscion guatucupa) population structure in waters adjacent to Rio de la Plata, environmental influence on its inter-annual variability. Estuar. Coast. Shelf S. 85, 89-96.

Jaureguizar A.J., Militelli, M.I., Guerrero, R.A., 2008, Environmental influence on maturity stage spatial distribution of whitemouth croaker (Micropogonias furnieri) along an estuarine gradient. J. Mar. Biol. Assoc. UK 88, 175-181.

Jaureguizar A.J., Ruarte C., Guerrero R., 2006b, Distribution of age-classes of striped weakfish (Cynoscion guatucupa) along an estuarine-marine gradient: correlations with the environmental parameters. Estuar. Coast. Shelf S. 67, 82-92.

Jaureguizar A.J., Waessle J.A., Guerrero R.A., 2007, Estuarine dynamics controlling the Atlantic searobins (Prionotus spp) distribution on Southwestern Atlantic Coastal System (34-41 $\left.{ }^{\circ} \mathrm{S}\right)$. Estuar. Coast. Shelf S. 73, 30-42.

Lucas, A.J., Guerrero R.A., Mianzan H.W., Acha E.M., Lasta C.A., 2005, Coastal oceanographic regimes of the Northern Argentine Continental Shelf $\left(34-43^{\circ} \mathrm{S}\right)$. Estuar. Coast. Shelf S. 65, 405420.

Massa A.M., 1998, Estructura poblacional del gatuzo (Mustelus schmitti) en la costa bonaerense y uruguaya asociado a condiciones ambientales. Tesis de Licenciatura Universidad Nacional 
de Mar del Plata, Argentina, 58 p, http://hdl.handle.net/1834/ 3584. Accessed 06 August 2015.

Massa A.M., Lasta C.A., Carozza C.R., 2004, Estado actual y explotación del gatuzo Mustelus schmitti. In: Sánchez R., Bezzi S. (Eds.) El Mar Argentino y sus recursos pesqueros, Tomo 4: Biología y evaluación del estado de explotación Publicaciones especiales INIDEP, Argentina, pp. 67-83.

Menni R.C., 1985, Distribución y Biología de Squalus acanthias, Mustelus schmitti y Galeorhinus galeus en el Mar Argentino en agosto-septiembre de 1987 (Chondrichthyes). Revista del Museo de la Plata (nueva serie), Sección Zoología 138, 151-182.

Menni R.C., Jaureguizar A.J., Stehmann M.F.W., Lucifora L.O., 2010, Marine biodiversity at the community level: zoogeography of sharks, skates, rays and chimaeras in the southwestern. Atlantic Biodivers. Conserv. 19, 775-796.

Oddone M.C., Paesch L., Norbis W., 2005, Reproductive biology and seasonal distribution of Mustelus schmitti (Elasmobranchii: Triakidae) in the Rio de la Plata oceanic front, south-western Atlantic. J. Mar. Biol. Assoc. U. K. 85, 1193-1198.

Pereyra I., Orlando L., Norbis W., Paesch L., 2008, Variación espacial y temporal de la composición por tallas y sexos del gatuso Mustelus schmitti Springer, 1939 capturado por la pesca de arrastre en la costa oceánica uruguaya durante 2004. Rev. Biol. Mar. Oceanogr. 43, 159-166.

Perry R.I., Smith S.J., 1994, Identifying Habitat Associations of Marine Fishes Using Survey Data: An Application to the Northwest Atlantic. Can. J. Fish Aquat. Sci. 51, 589-602.

Ruarte C., 2003, Informe de la campaña de evaluación de especies demersales costeras entre los $34^{\circ} \mathrm{y} 41^{\circ} 30^{\prime} \mathrm{S}$, Primavera 2003, Campaña EH-06/2003, Biblioteca INIDEP, Mar del Plata, p. 24.

San Martín M.A., Wiff R., Saavedra-Nievas J.C., Cubillos L.A., Lillo S., 2013, Relationship between Chilean hake (Merluccius gayi gayi) abundance and environmental conditions in the centralsouthern zone of Chile. Fis. Res. 143, 89-97.

Shepherd T., Page F., MacDonald B., 2002, Length and sex-specific associations between spiny dogfish (Squalus acanthias) and hydrographic variables in the Bay of Fundy and Scotian Shelf. Fish. Oceanogr. 11, 78-89.

Shono H., 2008, Application of the Tweedie distribution to zero-catch data in CPUE analysis. Fish. Res. 93, 154-162.
Simpfendorfer C.A., Heupel M.R., 2004, Assessing habitat use and movement. In: Carrier J.C., Musick J.A., Heithaus M.R. (Eds.), Biology of Sharks and Their Relatives, CRC Press, New York, pp. 553-572.

Simpfendorfer C.A., Yeiser B.G., Wiley T.R., Poulakis G.R., Stevens P.W., Heupel, M.R., 2011, Environmental Influences on the Spatial Ecology of Juvenile Smalltooth Sawfish (Pristis pectinata): Results from Acoustic Monitoring. PLoS One 6, e16918.

Sims D.W., 2003, Tractable models for testing theories about natural strategies: foraging behaviour and habitat selection of freeranging sharks. J. Fish Biol. 63, 5-73

Smith S.J., Page F.H., 1996, Associations between Atlantic cod (Gadus morhua) and hydrographic variables: implications for the management of the 4VsW cod stock. ICES J. Mar. Sci. 53, 15-24.

Speed C.W., Field I.C., Meekan M.G., Bradshaw C.J.A., 2010. Complexities of coastal shark movements and their implications for management. Mar. Ecol. Prog. Ser. 408, 275-293.

Stoner A.W., 2004, Effects of environmental variables on fish feeding ecology: implications for the performance of baited fishing gear and stock assessment. J. Fish Biol. 65, 1445-1471.

Venables W.N., Ripley B.D., 2002, Modern Applied Statistics with S, fourth edn. Springer, New York.

Vooren C.M., Klippel S., 2005, Ações para a Conservação de Tubarões e Raias no Sul do Brasil, Porto Alegre, Brasil, 261 p.

Walters C.J., Martell S.J.D., 2004, Fisheries Ecology and Management, Princeton University Press, Princeton, 448 p.

Whitfield A.K., Elliott M., 2002, Fishes as indicators of environmental and ecological changes within estuaries: a review of progress and some suggestions for the future. J. Fish Biol. 61, 229-250.

Wilberg M.J., Thorson J.T., Linton B.C., Berkson J., 2010, Incorporating time-varying catchability into population dynamic stock assessment models. Rev. Fish. Sci. 18, 7-24.

Wood S.N., 2006, Generalized Additive Models: An Introduction with R Chapman and Hall/CRC, Boca Raton, Florida.

Zuur A.F., Ieno E.N., Elphick C.S., 2010, A protocol for data exploration to avoid common statistical problems. Methods Ecol. Evol. $1,3-14$. 